\title{
TINGKAT AKURASI PENETAPAN NILAI JUAL OBJEK PAJAK BUMI TERHADAPNILAI PASAR DENGAN METODE ASSESSMENT SALES RATIO (STUDI KASUSPADAKECAMATAN MUARA SATU KOTA LHOKSEUMAWE)
}

\author{
Razif $^{1}$, Kasnah Wati ${ }^{2}$ \\ ${ }^{1,2}$ Prodi Akuntansi Fakultas Ekonomi dan Bisnis Universitas Malikussaleh Lhokseumawe \\ ${ }^{1}$ razifishak@gmail.com,${ }^{2}$ kasnahwati.ksp@gmail.com
}

\begin{abstract}
The purpose of this study is to determine the level of accuracy of the determination of the object tax selling value (NJOP) of the earth to market value by the method of assessment sales ratio in Muara Satu subdistrict, Lhokseumawe City. The data used is quantitative data presented in the form of numbers of NJOP and Market Value. The used sample used is 30 data on purchasing and selling transactions. The analytical method used isdescriptive quantitative and data analysis using descriptive statistics, which used the asessment sales ratio test which includes measurement of central tendency, measurement of variability (COD and COV), and Study Ratio.based on the result of the analysis, it can be concluded whit that: a) assessments sales ratio from each village is still not in accordance with the assessment ratio set by the local goverment, which is a minimum of $80 \%$. b) the results of the measurement of the central level of assessment tendency in the NJOP determination in th Muara Satu subdistrict area are not in the interval standard international assosiation of assessing officers (IAAO). c) NJOP variability measurements in muara satu subdistrict have been set at a different level of assessment.
\end{abstract}

Keywords: Tax Object Selling Value, Sales Ratio Assessment, Central Tendency, COD and COV.

\section{PENDAHULUAN}

Tanah merupakan salah satu properti berwujud (tangible property) yang sangat peka terhadap perkembangan. Perkembangan yang cukup pesat pada suatu daerah menyebabkan kenaikan permintaan berbagaiproperti pada pasar properti. Dengan adanya kenaikan permintaan tersebut maka harga properti cenderung meningkat. Dengan adanya perkembangan suatu daerah untuk tujuan tertentu seperti pembangunan daerahindustri ataupun komersial maka secara otomatis harga tanah didaerah tersebut cenderung meningkat.

Pajak merupakan sumber utama penerimaan negara yang digunakan untuk membiayai pengeluaran rutin maupun pembangunan agar tercapai kemakmuran dan kesejahteraan masyarakat. Hal tersebut tertuang dalam Anggaran Penerimaan dan Belanja Negara (APBN) dimana penerimaan pajak merupakan penerimaan dalam negeri yang terbesar. Pajak adalah iuran wajib bagi setiap warga negara yang harus dibayarkan kepada kas negara menurut ketentuan undang-undang yang berlaku yang bertujuan untuk membiayai pengeluaran umum negara sehingga dapat dipaksakan dan tidak adanya timbal jasa (kontraprestasi) secara langsung. Hal ini terjadi karena pajak adalah sumber pasti dalam memberikan kontribusi dana kepada negara yang merupakan cerminan dari kepedulian masyarakat dalam pembiayaan negara.
Penggolongan pajak berdasarkan lembaga pemungutannya di Indonesia dapat dibedakan menjadi dua yaitu Pajak Pusat dan Pajak Daerah.pajak pusat adalah pajak-pajak yang dikelola oleh Pemerintah Pusat yang dalam hal ini sebagian besar dikelola oleh Direktorat Jenderal Pajak Kementerian keuangan.Sedangkan pajak daerah adalah pajak-pajak yang dikelola oleh Pemerintah Daerah baik di tingkat Provinsi maupun Kabupaten atau Kota.Segala pengadministrasian yang berkaitan dengan pajak pusat, akan dilaksanakan di Kantor Pelayanan Pajak (KPP) atau Kantor Pelayanan Penyuluhan dan Konsultasi Perpajakan (KP2KP) dan Kantor Wilayah Direktorat Jenderal Pajak serta di Kantor Pusat Direktorat Jenderal Pajak. Untuk pengadministrasian yang berhubungan dengan pajak daerah, akan dilaksanakan di Kantor Dinas Pendapatan Daerah atau Kantor Pajak Daerah atau Kantor sejenisnya yang dibawahi oleh Pemerintah Daerah setempat (www.pajak.go.id).

StudiAssessment Sales Ratio sebagai salah satu alat yang dapat digunakan secara luas untuk mengevaluasi masalahyang ada kaitannya dengan Pajak Bumi dan Bangunan, baik itu menyangkut penetapan, keseragaman maupunkeadilan. Selain itu dapat juga digunakan untuk mengidentifikasi berbagai permasalahan seputar análisis pasar,penyelesaian keberatan prosedur penilaian dan masalah lainnya. Rasio yang sering digunakan dalam bidangpenilaian properti untuk 
kepentingan perpajakan adalah Assessment Ratio (AR) yang merupakan perbandinganantara Nilai Jual Objek Pajak (NJOP) sebagai nilai properti yang ditetapkan terhadap Nilai Pasar (market value).

Pertumbuhan Kota Lhokseumawe sangat pesat antara lain menyangkut pertumbuhan penduduk, ekonomi, sosial, dan budaya, disertai dengan peran dan status kotanya yang sangat cepat tersebut, memberikan implikasi dan konsekwensi pada pemenuhan tuntutan akan tersedianya lahan/tanah, baik untuk lokasi perumahan, kawasan industri, dan perdagangan, maupun untuk lokasi sejumlah perguruan tinggi. Kondisi ini memberikan dampak positif terhadap perkembangan nilai tanah dan bangunan yang berada dalam lingkup kawasan tersebut.

Dengan demikian Kecamatan Muara Satu Kota Lhokseumawe khususnya Kelurahan Batuphat Timur, Ujong Pacu dan Blang Pulo perlu diuji keakuratan penetapan NJOP dengan nilai pasarnya. Hal ini dimaksudkan untuk mengetahui seberapa besar rasio atau perbandingan yang ada antara lokasi pengembangan atau perumahan dengan perkampungan sekitar. Selain itu di daerah tersebut tingkat pertumbuhannya sangat pesat, khususnya menyangkut ekonomi, sosial, dan penduduk. Hal ini dapat dilihat, semakin banyaknya dibangun ruko-ruko, sehingga bisa dikatakan sebagai kawasan perdagangan, ditambah lagi daerah tersebut terdapat perguruan tinggi dan tempat wisata.

Adapun rumusan masalah dalam penelitian ini adalah : 1. Apakah Studi Assessment Sales Ratio pada masing-masing kelurahan di Kecamatan Muara Satu sudah sesuai dengan Assessment Ratio (AR) yang ditetapkan oleh Pemerintah Daerah Kota Lhokseumawe? 2. Apakah pengukuran tendensi sentral untuk penetapan NJOP di wilayah tersebut berada dalam interval standar International Association Of Assessing Officers (IAAO)? 3. Bagaimanakah pengukuran variabilitas untuk melihat keseragaman NJOP di masing-masing kelurahan Kecamatan Muara Satu.

Sedangkan tujuan dalam penelitian ini adalah : 1. Untuk mengetahui Studi Assessment Sales Ratio (AR) yang digunakan sebagai dasar penetapan Nilai Jual Objek Pajak (NJOP) Bumi di Kecamatan Muara Satu apakah sudah sesuai dengan Assessment Ratio (AR) yang ditetapkan oleh Pemerintah dalam meningkatkan penerimaan PBB di Kota Lhokseumawe. 2. Untuk mengetahui pengukuran tendensi dalam penetapan NJOP di Kecamatan Muara Satu berada dalam interval standar International Association of Assessing Officers (IAAO). 3. Untuk mengetahui pengukuran variabilitas NJOP di Kecamatan Muara Satu telah ditetapkan pada tingkat penilaian yang sama/seragam.

\section{TINJAUAN PUSTAKA}

\section{PENGERTIA PAJAK}

Susyanti, dkk (2015) Defenisi pajak berdasarkan undang-undang no. 28 tahun 2007 pasal 1 berbunyi sebagai berikut :

Pajak adalah kontribusi wajib kepada negara yang terutang oleh orang pribadi atau badan yang bersifat memaksa berdasarkan undangundang, dengan tidak mendapatkan imbalan secara langsung dan digunakan untuk keperluan negara bagi sebesar-besarnya kemakmuran rakyat.

Ciri-ciri yang ada dalam pengertian pajak tersebut adalah :

1. Pajak merupakan kontribusi wajib dari masyarakat kepada negara.

2. Dipungut berdasarkan UU dan aturan pelaksanaannya, sehingga sanksinya tegas dan bisa dipaksakan.

3. Tanpa kontra prestasi secara langsung

4. Dipungut oleh pemerintah pusat (Negara) maupun oleh pemerintah daerah (provinsi, kabupaten/kota)

5. Digunakan untuk membiayai pelaksanaan pemerintahan demi kemakmuran masyarat.

\section{PAJAK BUMI dan BANGUNAN}

Menurut Suandy (2011) Pajak Bumi dan Bangunan adalah pajak yang bersifat kebendaan dan besarnya pajak terutang ditentukan oleh keadaan objek yaitu bumi, tanah dan tau bangunan. Pengertian Pajak Bumi dan Bangunan menurut Undang-Undang No. 28 Tahun 2009 adalah pajak atas bumi dan bangunan yang dimiliki, dikuasai dan atau dimanfaatkan oleh orang pribadi atau badan, kecuali kawasan yang digunakan untuk kegiatan usaha perkebunan, perhutanan dan pertambangan.

Menurut Undang-Undang : "PBB adalah iuran yang dikenakan terhadap pemilik, pemegang kekuasaan, penyewa dan yang memperoleh manfaat dari bumi dan bangunan". pengertian bumi disini adalah termasuk permukaan bumi yang ada dibawahnya. Bumi menunjukkan pada permukaan bumi dan meliputi tanah dan perairan pedalaman serta laut wilayah Indonesia. Bangunan adalah konstruksi teknik yang ditanam atau diletakkan secara tetap pada tanah dan atau perairan dan digunakan sebagai tempat tinggal atau tempat berusaha.

\section{SubjekPajakBumidanBangunan}

Subjek PBB menurut Pasal 4 UU PBB adalah orang atau badan yang secara nyata mempunyai suatu hak atas bumi, dan atau memperoleh manfaat atas bumi, dan atau memiliki, menguasai, dan atau memperoleh manfaat atas bangunan. Selanjutnya dapat dirinci, 
bahwa yang dimaksud subjek diatas adalah terdiri dari orang atau badan yang :

1. Memiliki atau mempunyai hak atas bumi dan atau bangunan:

a.Memiliki atau mempunyai hak atas bumi (tanah) saja

b. Memiliki atau mempunyai hak atas bngunan saja

c.Memiliki atau mempunyai hak atas bumi (tanah dan bangunan).

2. Menguasai bumi dan atau bangunan :

a. Menguasai bumi (tanah)

b. Menguasai bangunan saja

c. Menguasai bumi (tanah) dan bangunan

3. Memperoleh manfaat atas bumi dan atau bangunan

a. Memperoleh manfaat atas bumi (atas) saja

b. Memperoleh manfaat atas bangunan saja

c. Memperoleh manfaat atas bumi (tanah) dan bangunan

\section{Objek Pajak Bumi dan Bangunan}

Berdasarkan pasal 2 Ayat (1) UU PBB, yang menjadi Objek Pajak PBB adalah bumi dan atau bangunan, permukaan bumi, tanah, (perairan) dan tubuh bumi yang ada dibawahnya. Sedangkan bangunan yang juga dijadikan objek PBB adalah konstruksi teknik yang ditanam atau diletakkan secara tetap pada tanah dan atau perairan. Selanjutnya penjelasan dari Pasal 1 Angka (2) UU PBB, menguraikan lebih lanjut mengenai pengertian bangunan yang menjadi objek PBB adalah :

a. Jalan lingkungan yang terletak dalam suatu komplek suatu bangunan seperti hotel, pabrik, dan emplasemennya, dan lain-lain yang merupakan satu kesatuan dengan kompleks bangunan tersebut.

b. Jalan TOL

c. Kolam renang

d. Pagar mewah

e. Tempat olahraga

f. Galangan kapal

g. Dermaga

h. Taman mewah

i. Tempat penampungan/kilang minyak air, gas dan pipa minyak

Dalam rangka memberikan manfaat kepada pemerintah atau berupaya dalam pelaksanaan pemungutan PBB secara adil maka undangundang memberikan kewenangan kepada Menteri Keuangan untuk mengatur tentang klasifikasi objek pajak bumi dan bangunan adalah pengelompokan bumi dan bangunan menurut nilai jualnya dan digunakan sebagai pedoman serta untuk memudahkan perhitungan pajak terhutang.

\section{NILAI JUAL OBJEK PAJAK}

Menurut Undang-Undang No. 12 Tahun 1994, menyatakan bahwa dasar pengenaan Pajak Bumi dan Bangunan adalah Nilai Jual Objek Pajak (NJOP). Nilai Jual Objek Pajak adalah "harga ratarata yang diperoleh dari transaksi jual beli yang terjadi secara wajar, NJOP ditentukan melalui perbandingan harga dengan objek lain yang sejenis, atau nilai perolehan baru, atau nilai jual objek pajak pengganti”. Besarnya NJOP tersebut digunakan sebagai dasar pengenaan PBB yang ditetapkan setiap tiga tahun sekali, ditetapkan oleh Menteri Keuangan kecuali untuk daerah tertentu ditetapkan setiap tahunnya sesuai dengan perkembangan daerahnya. Berdasarkan Keputusan Menteri Keuangan Republik Indonesia No 523/KMK.04/1998 tentang penentuan klasifikasi dan besarnya NJOP sebagai Dasar Pengenaan PBB yang mengatur pokok-pokok antara lain :

1. Pengertian NJOP seperti yang dijelaskan pada uraian diatas

2. Standar Investasi adalah jumlah yang diinvestasikan untuk suatu pembangunan dan/atau penanaman/penggalian jenis sumber daya alam atau budi daya tertentu yang dihitung berdasarkan komponen tenaga kerja, bahan dan alat mulai dari awal pelaksanaan pekerjaan sampai tahap produksi atau menghasilkan.

3. NJOP meliputi nilai jual objek permukaan bumi (tanah,perairan,dan wilayah laut di Indonesia) beserta kekayaan alam yang ada di bawah maupun di atasnya dan/atau bangunan di atasnya.

4. Objek pajak yang bersifat khusus adalah objek yang terletak, bentuk, peruntukan dan/atau penggunaannya mempunyai sifat dan karakteristik khusus.

5. Dalam hal objek pajak yang nilai jual permeternya lebih besar dari ketentuan NJOP, maka NJOP yang terjadi di lapangan digunakan sebagai dasar pengenaan $\mathrm{PBB}$.

6. Objek pajak sector pedesaan dan perkotaan yang tidak bersifat khusus NJOP nya ditentukan berdasarkan Nilai Indikasi Rata-rata (NIR) yang diperoleh dari hasil penilaian secara massal.

7. NJOP pada bangunan ditentukan berdasarkan pemeliharaan bangunan tersebut. Pemeliharaan bangunan dilihat dari konstruksi dan kapan (berdasarkan tahun) bangunan tersebut dibangun.

8. Besarnya NJOP sektor perkebunan, kehutanan, pertambangan serta usaha bidang perikanan, peternakan dan perairan untuk areal produksi ditentukan berdasarkan nilai jual permukaan bumi dan/atau bangunan ditambah dengan nilai 
investasi atau nilai jual pengganti atau dihitung secara keseluruhan berdasarkan nial jual pengganti.

9. Objek pajak yang bersifat khusus, NJOP nya dapat ditentukan berdasarkan nilai pasar yang dilakukan oleh pejabat fungsional penilai secara individu.

\section{ASSESSMENT SALES RATIO}

Menurut Hartoyo (2013) Assessment sales ratio (ASR) adalah "rasio atau perbandingan antara nilai yang digunakan untuk penetapan pajak suatu property terhadap nilai pasarnya". Assessment Sales Ratio Berdasarkan keputusan (Direktorat Jenderal Pajak dalam Tata Cara Perhitungan Masing-Masing, Key Performance Indicator (KPI) Lampiran 1 SE -18/PJ.22/2006 Tanggal 27 Juli 2006 ) yang dimaksud dengan Assessment sales ratio adalah "perbandingan ratarata Nilai Jual Objek Pajak (NJOP) PBB yang sudah ditetapkan dibandingkan dengan rata-rata harga pasar". berikut :

Formula perhitungannya adalah sebagai

\section{AssessmentSalesRatio}

$$
=\frac{\text { NJOP PBB yang sudah ditetapkan }}{\text { HargaPasar }} \times 100 \%
$$

Menurut Direktorat Jenderal Pajak dalam

Tata Cara Perhitungan Masing-Masing, ker Performance Indicator (KPI) Lampiran 1 SE18/PJ.22/2006 Tanggal 27 Juli 2006), mengemukakan bahwa perhitungan untuk Assessment Sales Ratio adalah sebagai berikut: penilaian property untuk kepentingan perpajakan adalah Assessment Sales Ratio (AR) yang merupakan perbandingan antara NJOP sebagai nilai property yang ditetapkan terhadap Nilai Pasar (market value). Analisis penentuan NJOP tanah dimaksudkan untuk melihat tingkat penerapan NJOP tanah terhadap nilai pasar yang berlaku. Studi Assessment Sales Ratio dapat member informasi umum apakah NJOP yang ditetapkan lebih tinggi atau lebih rendah dari pasar.

INTERNATIONAL ASSOCIATION OF ASSESSING OFFICERS (IAAO)

International Association of Assessing Officers (IAAO) adalah sebuah organisasi internasional yang melakukan penelitian, menyelenggarakan pendidikan, menetapkan standar penilaian administrasi, menyediakan jasa profesi penilaian properti dan hal lain yang berhubungan dengan pajak properti yang berpusat di Amerika Serikat, tepatnya di 314 West $10^{\text {th }}$ St. Kansas City, Missouri.

Sebagian besar anggota IAAO adalah orang-orang yang berprofesi sebagai penilai properti, yang biasanya bekerja untuk pemerintah, tapi pada dasarnya juga terbuka untuk siapapun yang bekerja untuk industri, akademik, atau bidang-bidang umum lainnya yang berminat dengan penilaian properti.

Standar Pengukuran Akurasi Penetapan NJOP terhadap Nilai Pasar menurut IAAO adalah sebagai berikut:

a. Jika mean/median > 1,10 (110\%) berarti over-assessment

b. Jika mean/median< $0,90 \quad(90 \%)$ berarti under-assessment

c. Jika mean/weighted mean $>1,10$ (110\%) berarti terjadi regresivitas

d. Jika mean/weighted mean $<0,90(90 \%)$ berarti terjadi progresivitas

\section{METODE PENELITIAN}

Objek Penelitian

Objek dalam penelitian ini adalah data PPAT yang saya peroleh dari Kecamatan Muara Satu Kota Lhoseumawe dan Data Niai Jual Objek Pajak (NJOP) dari Kantor Dinas Pendapatan Daerah Kota Lhokseumawe selama tahun 2017.

\section{Populasi dan Sampel}

Populasi dalam penelitian ini adalah 131 data transaksi jual beli tanah kosong dan juga bangunan yang terjadi di Kecamatan Muara Satu Kota Lhokseumawe selama tahun 2017.Dalam penelitian ini teknik pengambilan sampel yang digunakan adalah convenience sampling atau teknik pengambilan sampel secara kebetulan (aksidental sampling). Aksidental sampling merupakan teknik penentuan sampel berdasarkan kebetulan, yaitu sampel mana saja yang secara kebetulan bertemu dengan peneliti dapat digunakan sebagai sampel, bila dipandang objek yang kebetulan ditemui itu cocok sebagai sumber data. Sampel dalam penelitian ini adalah 30 data transaksi jual beli tanah kosong dan bangunan yang terdiri dari 3. kelurahan yaitu Batuphat Timur, Ujung Pacu dan Blang Pulo.

\section{Prosedur Penelitian}

berikut: Prosedur penelitian adalah sebagai

1. Mengajukan permohonan penelitian

2. Disposisi pimpinan

3. Pengumpulan data

4. Analisis data penelitian

5. Kesimpulan dan saran

\section{Jenis Data}

Hasan (2006) menjelaskan bahwa, Jenis data dapat dibagi menjadi:

1. Data Kualitatif adalah data yang tidak berbentuk bilangan.

Contoh: Kelamin, agama, atau warna.

2. Data Kuantitatif adalah data yang berbentuk bilangan.

Contoh: Tinggi, panjang, atau umur. 
Jenis data yang digunakan dalam penelitian ini berupa data kuantitatif. Data ini disajikan dalam bentuk angka-angka berupa nilai NJOP dan Nilai Pasar.

\section{Sumber Data}

Sunyoto (2013) menyatakan bahwa, dilihat dari sumbernya maka data yang digunakan dalam penelitian ini adalah data primer dan data sekunder.

1. Data Primer

Data NJOP Kecamatan Muara Satu Kota Lhokseumawe selama tahun 2017. Data ini diperoleh di Kantor Dinas Pendapatan Daerah Kota Lhokseumawe.

2. Data Sekunder

Data transaksi jual beli tanah kosong di Kecamatan Muara Satu Kota Lhokseumawe selama tahun 2017. Data ini diperoleh dari laporan PPAT yang dilaporkan setiap bulannya oleh camat dan notaris ke Kantor Dinas Pendapatan Daerah Kota Lhokseumawe. Data demografis dan geografis, data ini diperoleh dari Kantor Kecamatan Muara Satu Kota Lhokseumawe.

\section{Teknik Pengumpulan Data}

\section{Metode Wawancara (Interview)}

Sugiyono (2010), menjelaskan bahwa metode Wawancara ini merupakan pertemuan dua orang untuk bertukar informasi dan ide melalui tanya jawab, sehingga dapat dikonstruksikan makna dalam suatu topik tertentu. Peneliti menggunakan teknik wawancara terhadap Kepala Kantor Dinas Pendapatan Daerah Kota Lhokseumawe dan Kepala Kantor Kecamatan Muara Satu Kota Lhokseumawe.

\section{Metode Observasi (Observation Methods)}

Danang (2013), menyatakan bahwa Metode Observasi merupakan suatu metode yang digunakan oleh peneliti dengan cara pengamatan langsung terhadap kegiatan yang dilaksanakan perusahaan. Peneliti melakukan observasi langsung ke Kantor Dinas Pendapatan Daerah yang berada di Kota Lhokseumawe untuk mendapatkan data Nilai Jual Objek Pajak (NJOP) yang terjadi di Kecamatan Muara Satu selama kurun waktu 2017, dan kantor Kecamatan Muara Satu Kota Lhokseumawe untuk mendapatkan Data Geografis dan Data Demografi serta data transaksi jual beli tanah dalam kurun waktu 2017. Data lainnya yaitu dari literature atau daftar pustaka serta referensi penelitian seperti jurnal skripsi sebelumnya, dan buku-buku yang berhubungan dengan penelitian ini.

\section{DEFINISI OPERASIONAL VARIABEL}

1. Assessment Ratio (AR) adalah rasio atau perbandingan antara nilai yang digunakan untuk penetapan pajak suatu properti terhadap nilai pasarnya.

2. Nilai Jual Objek Pajak (NJOP) tanah PBB adalah besarnya NJOP tanah dalam Surat Pemberitahuan Pajak Terutang (SPPT) PBBuntuk ketetapan tahun 2017.

3. Nilai atau harga pasar adalah harga transaksi atau harga jual beli yang terjadi.

4. Nilai atau harga pasar ini didapat dari agen atau broker properti.

5. Nilai atau harga yang dilaporkan adalah harga transaksi jual beli yang dilaporkan oleh notaris/PPAT setiap bulan selama tahun 2017 kepada KPP Pratama.

6. Variabilitas adalah suatu pengukuran yang berguna untuk menganalisis tingkat keseragaman penetapan NJOP di suatu daerah tertentu. Apabila penetapan NJOP disuatu daerah seragam artinya NJOP yang sudah ditetapkan mendekati sama dengan nilai objek pajak yang sebenarnya (harga jual), berarti kinerja penetapan sudah bagus.

\section{METODE ANALISIS DATA}

Studi Rasio

Studi rasio digunakan untuk membandingkan Nilai Jual Objek Pajak dengan nilai pasar. Sesuai dengan SE-09/PJ.06/2003 disebutkan bahwa standar Assessment Ratio yang ditetapkan oleh pemerintah minimal $80 \%$. Secara matematis, cara perhitungannya sebagai berikut:

$$
\begin{aligned}
& A R=\frac{\mathrm{Ai}}{\mathrm{Si}} \times 100 \% \\
& \text { Keterangan : } \\
& \mathrm{AR}=\text { Assessment Ratio } \\
& \mathrm{Ai}=\text { Nilai yang ditetapkan suatu properti } \\
& \text { (NJOP) } \\
& \mathrm{Si}=\text { Nilai Pasar (Market Value) }
\end{aligned}
$$

\section{Pengukuran Tendensi Sentral}

Pengukuran Tendensi Sentral digunakan untuk mengetahui apakah penetapan NJOP di Kecamatan Muara Satu Kota Lhokseumawe berada dalam interval standar IAAO, yaitu assessment berada pada level 90\%-110\%.

\section{a. Mean (Rata-Rata Hitung)}

Yaitu total nilai dari Assessment Ratio (AR) dibagi dengan jumlah observasi. Secara matematis, cara perhitungannya sebagai berikut:

Keterangan:

$$
\text { ARmean }=\frac{\Sigma \mathrm{Ai} / \mathrm{Si}}{\mathrm{n}}
$$

$$
\begin{array}{ll}
\Sigma(\mathrm{Ai} / \mathrm{Si}) & =\text { Jumlah seluruh ratio } \\
\mathrm{n} & =\text { Ukuran sampel }
\end{array}
$$

b. Median (Nilai Tengah)

Yaitu angka tengah yang diperoleh apabila data disusun dari nilai terendah hingga nilai tertinggi. Nilai ini 
berhubungan dengan posisi sentral yang dimilikinya dalam sebuah distribusi.

\section{c. Weighted Mean}

Yaitu rata-rata hitung tertimbang dari suatu observasi, dalam hal ini total nilai dari NJOP bumi dibagi dengan total nilai pasar seluruh sampel obyek pajak observasi. Secara matematis, perhitungannya sebagai berikut:

$$
\text { ARweightedmean }=\frac{\Sigma \mathrm{A}}{\Sigma \mathrm{S}}
$$

Keterangan:

$\Sigma \mathrm{A}=$ Total Jumlah NJOP

$\Sigma \mathrm{S}=$ Jumlah Total Nilai Pasar

d. Mean Dibagi Dengan Median

Jika jumlah data (sampel) sekurangkurangnya 30, aturan umum yang dapat digunakan untuk menerjemahkan hasil rasio atau perbandingan antara meandan medianadalah sebagai berikut:

1. Jika mean/median rasionya lebih dari $1,10(110 \%)$ merupakan indikasi terjadinya over assessment.

2. Jika mean/median rasionya kurang dari 0,90 (90\%) merupakan indikasi terjadinya under assessment.

e. Mean dibagi dengan Weighted Mean Jika jumlah data (sampel) sekurangkurangnya 30, aturan umum yang dapat digunakan untuk mengukur hasil rasio atau perbandingan antara mean dan weighted mean adalah sebagai berikut:

1. Jika mean/weightedmean rasionya lebih dari 1,10 (110\%) merupakan indikasi terjadinya regresivitas, berarti properti yang lebih rendah nilai pasarnya ditentukan NJOP-nya (assessed) pada persentase yang lebih tinggi daripada properti (obyek pajak) yang lebih tinggi nilai pasarnya.

2. Jika mean/weightedmean rasionya kurang dari 0,90 (90\%) merupakan indikasi terjadinya progresivitas, berarti properti yang lebih rendah nilai pasarnya ditentukan NJOP-nya (assessed) pada persentase yang lebih rendah daripada properti yang lebih tinggi nilai pasarnya.

\section{Pengukuran Variabilitas}

Pengukuran variabilitas digunakan untuk mengetahui tingkat keseragaman dan tingkat variabilitas penetapan NJOP tiap kelurahan di Kecamatan Muara Satu Kota Lhokseumawe. Di samping itu, pengukuran ini juga berguna untuk melihat kinerja penilaian atau penetapan sehingga dapat diketahui apakah pada Kecamatan Muara Satu perlu dilakukan penilaian ulang atau tidak. Kriteria koefisien dispersi dan koefisien variasi yang layak juga ditentukan oleh IAAO.

a. Koefisien Dispersi (Coefficient of Dispersion)

Menurut Rossini dan Paul Kershaw (2006), koefisien dispersi adalah ukuran keseragaman menggunakan nilai median. Semakin rendah COD, semakin baik penentuan NJOP-nya (assessment). Hal ini berarti properti-properti (objek pajak) yang serupa telah ditentukan NJOPnya pada suatu tingkat akurasi yang relatif sama. Analisis ini digunakan untuk mengetahui besarnya penyimpangan yang terjadi dalam menentukan besarnya NJOP dengan menggunakan perhitungan COD dengan tidak memerlukan asumsi kenormalan distribusi.

Perhitungan dilakukan dengan cara membagi rata-rata deviasi absolut dengan rasio median lalu dikalikan dengan $100 \%$. Rata-rata deviasi absolut didapat dengan cara mengurangkan rasio median dari setiap rasio sampel, menjumlahkan hasilnya tanpa menghiraukan nilai positif atau negatif, lalu membaginya dengan jumlah sampel. Kriteria COD untuk menentukan NJOP adalah sebagai berikut:

1. COD < 20\%: tingkat keseragaman penetapan NJOP adalah tinggi, menghasilkan kualitas yang baik dalam melakukan penilaian untuk penetapan NJOP.

2. COD > 20\%: tingkat keseragaman penetapan NJOP adalah rendah, menghasilkan kualitas yang buruk dalam melakukan penilaian untuk penetapan NJOP.

b. Koefisien Variasi (Coefficient of Variation)

Menurut Rossini dan Paul Kershaw (2006), koefisien variasi adalah ukuran keseragaman dengan menggunakan nilai mean. Semakin rendah COV, semakin baik penentuan NJOP-nya (assessment) berarti properti-properti (obyek pajak) yang serupa telah ditentukan NJOPnya pada suatu tingkat akurasi yang relatif sama. Aturan umum sehubungan dengan tingkat COV adalah bahwa keseragaman penentuan nilai dapat dikatakan baik jika COV sama atau kurang dari $25 \%$. $\mathrm{COV}$ dihitung dengan cara membagi standar deviasi dengan mean rasio dan mengalikannya dengan $100 \%$. Varians diperoleh dengan cara mengurangkan mean rasio dari setiap rasio, 
mengkuadratkan selisihnya, menjumlahkan selisih yang telah dikuadratkan, dan membaginya dengan jumlah sampel dikurangi satu. Standar deviasi dihitung dengan mengakarkan varians.

\section{GAMBARAN UMUM OBJEK PENELITIAN}

Kecamatan Muara Satu merupakan salah satu dari Empat Kecamatan yang berada diwilayah Kota Lhokseumawe, Aceh, Indonesia dengan Ibukota Kecamatan Batuphat, Luas Kecamatan $55.90 \mathrm{Km}^{2}$ yang terdiri dari 11 Desa, 39 Dusun serta tinggi tempat DPL 0.5-10 M. Batas-batas Kecamatan Muara Satu Kota Lhokseumawe yaitu : Utara : Selat Malaka

Selatan : Kecamatan Nisam, Kabupaten Aceh Utara

Barat :Kecamatan Dewantara, Kabupaten Aceh Utara

Timur : Kecamatan Muara Dua, Kota Lhokseumawe

Table 1

Nama-Nama Desa Kecamatan Muara Satu

Kota Lhokseumawe Tahun 2017

\begin{tabular}{|c|l|}
\hline Kemukiman & \multicolumn{1}{|c|}{ Gampong } \\
\hline \multirow{5}{*}{ Paloh Timur } & Desa Blang Panyang \\
& Desa Meunasah Dayah \\
& Desa Cot Trieng \\
& Desa Meuria Paloh \\
& Desa Paloh Punti \\
& Desa Padang Sakti \\
\hline \multirow{5}{*}{ Paloh Barat } & Desa Blang Pulo \\
& Desa Batuphat Timur \\
& Desa Blang Naleung Mameh \\
& Desa Ujong Pacu \\
& Desa Batuphat Barat \\
\hline
\end{tabular}

Sumber : Kantor Camat Muara Satu

Perkembangan penduduk di Kecamatan Muara Satu Kota Lhokseumawe semakin bertambah setiap tahunnya dimasing-masing kelurahan, baik itu bagi pendatang atau yang pindah dari kota lain ke kota Lhokseumawe khususnya di Kecamatan Muara Satu, dengan demikian sudah terlihat jelas bahwasanya permintaan terhadap tempat tinggal atau bangunan (perumahan) semakin meningkat, yang ditandai dengan banyaknya penduduk yang menyewa bahkan membeli bumi atau bangunan yang berada Di Kota Lokseumawe khusunya dikawasan Kecamatan Muara Satu demi memudahkan segala aktivitas/urusan mereka masing-masing baik itu dikalangan siswa, mahasiswa/i maupun tenaga kerja yang bekerja diwilayah tersebut.

\section{ANALISIS DATA}

Data yang di analisis dalam studi ratio adalah Nilai Pasar tanah yang merupakan
Market Value, dan Nilai Jual Objek Pajak (NJOP) tanah yang merupakan Assessment Value. Dengan menggunakan metode convenience sampling, jumlah sampel yang terpilih adalah 30 kasus terdiri dari dari eiga Kelurahan.

\section{Studi Rasio}

Pengujian ini digunakan untuk mengetahui apakah ada perbedaan antara NJOP tanah dan bangunan dengan nilai pasarnya. Jika level of assesment berada pada tingkat $100 \%$ (standar nilai tengah 1,00) berarti tidak ada perbedaan antara NJOP tanah dan bangunan dan nilai pasar. Jika level of assesment berada dibawah $100 \%$ menandakan penetapan NJOP tanah dan bangunan di bawah nilai pasar, sedangkan jika level of assessment berada diatas $100 \%$ menandakan bahwa penetapan NJOP di atas nilai pasar.

Tujuan dari Assessment Ratio yaitu untuk membandingkan Nilai Jual Objek Pajak (NJOP) dengan Nilai Pasar. Dalam penelitian ini nilai pasar ditunjukkan dengan harga nilai jual. Dari perhitungan studi ratio dapat dilihat pada lampiran 2 dan diperoleh hasil perhitungan seperti yang terlihat pada tabel 2 dibawah ini :

Tabel 2

Assessment Ratio (AR) Per Kelurahan

\begin{tabular}{|l|c|c|l|}
\hline Kelurahan & AR & AR\% & Kesimpulan \\
\hline $\begin{array}{l}\text { Batuphat } \\
\text { Timur }\end{array}$ & 0,542 & 54,2 & Under Assessment \\
\hline Blang Pulo & 0,985 & 98,5 & Under Assessment \\
\hline Ujung Pacu & 0,745 & 74,5 & Under Assessment \\
\hline
\end{tabular}

Sumber : Data Olahan

\section{Pengukuran Tendensi Sentral}

Pengukuran tendensi sentral ini bertujuan untuk mengetahui besarnya mean, median, median weighted mean, perbandingan antara mean dan median serta perbandingan antara mean dengan weighted mean sehingga dapat diketahui apakah di Kecamatan Muara Satu under-assessment atau overassessment juga dapat diketahui apakah terjadi progresivitas atau regresivitas atau mungkin tidak terjadi keduanya (proportional). Pengukuran tendensi sentral dengan menggunakan data rasio diolah dengan menggunakan Microsoft Excel. Pada Tabel 4.6 dikemukakan ringkasan hasil pengukuran tendensi sentral di Kecamatan Muara Satu untuk Tahun 2017.

\section{Mean}

Merupakan rata-rata hitung dari jumlah total Assessment Ratio dengan jumlah objek pajak yang diteliti (Sampel). Berikut ini penghitungan Mean dari Assessment Ratio:

$$
\text { ARMean }=\frac{\sum \mathrm{Ai} / \mathrm{Si}}{30}=\frac{22,72}{30}=0,757
$$

Dari perhitungan ARmean diatas Rata-rata hitung dari total Assessment Ratio adalah 0,757 
atau $75,7 \%$ yang berasal dari penjumlahan antara jumlah nilai yang ditetapkan untuk suatu property (NJOP) yang dibagi dengan jumlah nilai pasar yang memiliki nilai yaitu 22,72 yang telah dibagi dengan rata-rata sampel yaitu 10 , kemudian dibagi dengan seluruh sampel penelitian, yang jumlah sampel tersebut sebanyak 30 sampel. Untuk lebih jelasnya bisa dilihat pada lampiran 1 dan lampiran 2 yang tertera jelas untuk semua jumlah sampel per kelurahan.

\section{Median}

Merupakan nilai tengah dari rasio-rasio tersebut. Dari tabel 4.6 di atas dapat diketahui $\mathrm{AR}_{\text {Median }}$ sebesar 0,55. Angka 0,55 didapat dari mengurutkan AR tiap sampel dari yang terkecil hingga yang terbesar, nilai yang di tengah merupakan median. Karena sampel berjumlah genap yaitu 30, maka setelah diurutkan didapat AR 0,55 dan 0,55 yang berada di tengah (urutan ke-15 dan ke-16), jadi kedua AR ini ditambah dan dibagi dua, sehingga didapat hasil 0,55. Median (nilai tengah) dapat dilihat pada lampiran 4 pada kolom AR yang sudah diurutkan dari yang terkecil hingga yang terbesar sehingga mendapatkan hasil yaitu 0,55 .

\section{Weighted Mean}

$$
\begin{aligned}
& \text { WeigtedMean }=\sum \frac{\mathrm{NJOP}}{\text { NilaiPasar }} \\
& +\frac{\operatorname{Rp~493.118.947~}}{\operatorname{Rp} 1.725 \cdot 100.000}=0,285
\end{aligned}
$$

Dari perhitungan diatas dapat kita ketahui bahwa rata-rata tertimbang dari rasio-rasio tersebut adalah 0,286 atau 28,6\% yaitu hasil dari pembagian antara seluruh jumlah Nilai Jual Objek Pajak dari ke 30 sampel penelitian dengan seluruh Nilai Pasar dan untuk lebih jelasnya bisa dilihat pada lampiran 1, hal ini dapat diartikan bahwa tingkat Assessment Ratio untuk Kecamatan masih rendah, karena tidak sesuai dengan standar yang ditetapkan oleh The International Association of Assessing Officers, yang menyatakan bahwa tingkat Assessment Ratio untuk semua objek pajak dalam suatu daerah seharusnya berada dalam $10 \%$ dari tingkat rasio yang diinginkan yaitu antara $90 \%$ sampai dengan $110 \%$. Dari perhitungan Mean, Median, dan Weighted Mean dapat kita ketahui kualitas tingkat penentuan NJOP serta terjadinya progesivitas atau regresivitas pada Kecamatan Muara Satu.

\section{Mean/Median}

$$
\frac{\text { Mean }}{\text { Median }}=\frac{0,757}{0,55}=1,376
$$

Hal ini menunjukkan bahwa nilai mean 0,757 dibagi dengan nilai median 0,55 yang dihasilkan berada diatas standar yang ditetapkan The International Association Of Assessing Officer, yaitu 0,90 sampai dengan 1,10 . Jika mean/median rasionya kurang dari 0,90 , maka hal ini merupakan indikasi terjadinya under assessment. Jika mean/median rasionya lebih dari 1,10, maka hal ini merupakan indikasi terjadinya over assessment. Karena rasio mean/median di Kecamatan Muara Satu berada dalam situasi over asessment maka bisa dikatakan bahwa penetapan NJOP berada diatas nilai pasar.

\section{Mean/Weighted Median}

$$
\begin{aligned}
& \frac{\text { Mean }}{\text { Weighted Mean }}=\frac{0,757}{0,286}=2,647 \\
& \text { Hasil perhitungan mean } 0,757 \text { dibagi }
\end{aligned}
$$
dengan weighted mean 0,286 seperti nilai yang tertera pada tabel 4.6 menunjukkan hasil sebesar 2,647 hal ini berarti terjadi regresivitas dalam penetapan NJOP di Kecamatan Muara Satu Kota Lhokseumawe, karena hasilnya $>1,10$ sesuai standar The International Association Of Assessing Officer yang sah.

\section{Pengukuran Variabilitas}

Pengukuran variabilitas digunakan untuk mengetahui tingkat keseragaman dan tingkat variabilitas penetapan NJOP tiap kelurahan di Kecamatan Muara Satu. Di samping itu, pengukuran ini juga berguna untuk melihat kinerja penilaian atau penetapan sehingga dapat diketahui apakah perlu penilaian ulang di Kecamatan Muara Satu atau tidak. Hasil pengukuran variabilitas dengan menggunakan perhitungan COD adalah $38,18 \%$ yang dihitung dengan cara membagi ratarata deviasi absolut dengan rasio median lalu dikalikan dengan $100 \%$. Rata-rata deviasi absolut didapat dengan cara mengurangkan rasio median dari setiap rasio sampel, menjumlahkan hasilnya dengan tidak menghiraukan nilai positif atau negatif, lalu membaginya dengan jumlah sampel.

$$
\begin{gathered}
\text { Rata }- \text { Rata Deviasi Absolut }=\frac{6,22}{30} \\
=0,438 \\
\text { COD }=\frac{0,438}{0,55} \times 100 \%=79,636
\end{gathered}
$$

Perhitungan COD secara lengkap dapat dilihat pada Lampiran 4. Sedangkan COV dapat dihitung dengan cara membagi standar deviasi dengan mean rasio dan mengalikannya dengan $100 \%$. Varians diperoleh dengan cara mengurangkan mean rasio dari setiap rasio, mengkuadratkan selisihnya, menjumlahkan selisih yang telah dikuadratkan, dan membaginya dengan jumlah sampel dikurangi satu. Standar deviasi dihitung dengan mengakarkan varians. 
Volume 7, Nomor 1, Februari 2019

$$
\begin{aligned}
& \begin{array}{l}
\text { Varians } \\
\text { jumlah selisih yang telah dikuadratkan }
\end{array} \\
& \quad=\frac{14,235}{29}=0,490862 \\
& \text { Standar Deviasi }=\sqrt{\text { varians }}=\sqrt{ } 0,490862= \\
& 0,701 \\
& \text { COV }=\frac{\text { Standar Deviasi }}{\text { AR Mean } x 100 \%=\frac{0,701}{0,757} \times 100 \%=92,} \\
& \text { Perhitungan COV secara lengkap dapat dilihat } \\
& \text { pada Lampiran 5. Dengan melihat hasil } \\
& \text { perhitungan diatas, didapat hasil penetapan NJOP } \\
& \text { di Kecamatan Muara Satu Kota Lhokseumawe } \\
& \text { bahwasanya ketetapan yang terjadi ternyata tidak } \\
& \text { seragam, hal tersebut dapat terlihat dari nilai COD } \\
& \text { yang lebih besar dari 20\% dan COV yang lebih } \\
& \text { besar dari } 25 \% \text {. Hal ini tidak sesuai dengan standar } \\
& \text { yang dikeluarkan oleh The International } \\
& \text { Association Of Assessing Officer (IAAO) bahwa } \\
& \text { ukuran COD yang baik harus lebih kecil atau } \\
& \text { sama dengan 20\% dan COV lebih kecil atau sama } \\
& \text { dengan 25\%. }
\end{aligned}
$$

\section{PEMBAHASAN}

\section{Hasil Pengukuran Studi Rasio}

Kecamatan Muara

Satu Kota

Lhokseumawe dipilih oleh peneliti sebagai wilayah penelitian karena merupakan salah satu wilayah yang perkembangan wilayahnya cukup pesat khususnya pada kelurahan Batuphat Timur, karena kelurahan tersebut adalah wilayah yang termasuk kota sehingga nilai tanah dan beangunannya selalu mengalami kenaikan. Sebuah rumah baik diwilayah perumahan maupun perkampungan tidak hanya dijadikan sebagai tempat tinggal (rumah tinggal), tetapi juga dijadikan sebagai asset (invest) yang lebih bermanfaat yaitu rumah tersebut dapat dikontrakan (disewakan), seperti contoh banyak perumahan-perumahan yang berada diwilayah Blang Pulo, Batuphat Timur dan Ujong Pacu serta wilayah lainnya yang ditempati oleh kebanyakan mahasiswa dari dalam maupun luar daerah yang sangat membutuhkan tempat tinggal karena berdekatan dengan perguruan tinggi maupun tempat yang dekat dengan kawasan wisata.

Pada uji Assessmen Ratio baik didaerah perumahan maupun perkampungan di setiap kelurahan yang telah peneliti teliti ternyata telah terjadi under assesment dengan nilai Kelurahan Batuphat Timur 54,2\%, Kelurahan Blang Pulo 98,5\%, dan Kelurahan Ujung Pcu 74,55, karena pnenetapan NJOP masih dibawah harga pasar, dengan kata lain nilai tanah dan bangunan belum mencapai standar yang ditetapkan oleh pemerintah. Sedangkan standar yang telah ditetapkan oleh pemerintah yaitu $80 \%$, yang artinya penetapan NJOP bumi dan bangunan sama atau mendekati harga pasar. Namun hasil analisis menyatakan bahwa assesment ratio pada tiap kelurahan telah terjadi under assesment, hal tersebut terjadi karena tingginya harga tanah dan bangunan, sedangkan NJOP nya sangat rendah.

Hasil analisis didapat bahwa tingkat assesment ratio pada wilayah Blang Pulo, Batuphat Timur, dan Ujung Pacu untuk tahun 2017 masih berada dibawah standart yang ditetapkan oleh Dewan Pengelola Keuangan Aset Daerah (DPKAD) kota Lhokseumawe, karena NJOP yang , 9 9tetapkan masih dibawah harga pasar, sehingga dihasilkan Level Of Assesment yang sangat rendah. Sampai dengan saat ini DPKAD belum bisa menyesuaikan NJOP dengan nilai pasarnya, karena wajib pajak merasa keberatan dan tidak mau menbayar PBB jika NJOP tinggi, dengan kata lain jika NJOP sama atau diatas harga pasar, maka pajak yang dibayar juga akan tinggi. Selain itu juga dengan NJOP yang tinggi wajib pajak akan bereaksi dan akan mengajukan keberatan, sedangkan pengajuan keberatan tidak manunda pembayaran pajaknya. Karena itu, DPKAD berasumsi bahwa lebih baik ditetapkan NJOP yang rendah dan wajib pajak mau membayar pajaknya dari pada dengan NJOP yang tinggi wajib pajak tidak mau membayar.

\section{Hasil Pengukuran Tendensi Sentral}

Dari hasil pengukuran tendensi sentral pada Assessment Rasio Mean dapat kita ketahui bahwa tingkat assessment ratio di Kelurahan Batuphat Timur, Kelurahan Blang Pulo dan Kelurahan Ujong Pacu masih rendah karena diperoleh hasil 0,757 atau 75,7\% dan masih belum ada kriteria adil itu bisa terlihat dari hasil Mean dibagi dengan Median yang diperoleh hasilnya yaitu $1,376 \%$ artinya belum memenuhi standar yang ditetapkan oleh IAAO, yang menyatakan bahwa tingkat assesment ratio untuk semua objek pajak dalam suatu daerah seharusnya berada dalam $10 \%$ dari tingkat ratio yang diinginkan yaitu antara 90\% sampai dengan $110 \%$. Dengan kata lain, baik wilayah perumahan maupun perkampungan penetapan NJOP berada di bawah harga pasar tanah dan bangunan. Hasil analisis tersebut merupakan nilai tengah dari keseluruhan sampel perumahan dan perkampungan. Analisis tersebut juga menunjukkan bahwa penetapan NJOP, baik pada perumahan maupun perkampungan sama-sama berada di bawah nilai pasar.

Pengukuran tendensi sentral pada weight mean, dihasilkan 0,286, Hasil analisis belum memenuhi standar ratio IAAO dan belum mencapai keseragaman atau tidak adil, dimana tingkat ratio yang diinginkan yaitu antara $90 \%$ dan $110 \%$. Data yang diambil dalam penelitian ini cenderung berimbang antara yang berada dibawah nilai ratarata assessment sales ratio dengan yang berada di atas nilai rata-rata assessment sales ratio. Hal ini tampak dalam hasil pengukuran tendensi sentral dari mean/median yang menunjukkan perbandingan NJOP terhadap Nilai Pasar sebesar 1,376. 
Dikatakan dibawah nilai rata-rata assessment sales ratio adalah dimana penetapan NJOP jauh dibawah nilai pasar. Sedangkan diatas nilai rata-rata assessment ratio dimana NJOP mendekati harga pasar. Hal tersebut menunjukkan bahwa dari masing-masing kelompok properti yaitu perumahan dan perkampungan harga pasarnya bervariasi. Harga suatu tanah dan bangunan dikatakan bervariasi karena nilai tanah dan bangunan pada setiap properti berbeda, hal ini bisa dilihat dari kondisi tanah, konstruksi bangunan, faktor lingkungan, dan fasilitas yang tersedia pada kelompok properti perumahan. Dan hasil pengukuran tendensi sentral dikatakan berimbang karena pada kedua kelompok propeti tersebut adalah lebih besar 0,90 dan kurang dari 1,10.

Sedangkan pada mean/weight mean, hasil anliasis menunjukkan assessment sales ratio tidak tergantung pada nilai pasar (nilai pasar yang sebenarnya). Pada kenyatannya assessment sales ratio tergantung pada seberapa besar harga pasar yang diinginkan wajib pajak untuk dijadikan sebagai dasar penetapan NJOP.

\section{Hasil Pengukuran Variabilitas}

Karena dari hasil analisis menunjukkan nilai COD sebesar $79,636 \%$ pada Pengukuran variabilitas menunjukkan bahwa penetapan NJOP pada Kelurahan Batuphat Timur, Blang Pulo dan Ujung Pacu masih belum seragam. Sedangkan standar yang ditentukan oleh IAAO sebesar $20 \%$. Begitu pula dengan nilai COV sebesar 92,602, dimana nilai tersebut cukup tinggi dari standar yang telah ditentukan oleh IAAO yaitu $20 \%$. Ketidakseragaman ini, dikarenakan penetapan NJOP masih belum sesuai dengan keadaan objek pajak yang sebenarnya. Ada beberapa objek pajak yang nilainya tinggi, namun NJOP nya masih rendah, sedangkan objek pajak yang nilainya cukup rendah penetapan NJOP nya sama dengan objek pajak yang nilainya tinggi. Hal yang menyebabkan tingkat penetapan NJOP tidak seragam yaitu masih belum dilaksanakannya penilaian ulang khususnya untuk kalompok properti perumahan, sementara harga pasarnya selalu mengalami kenaikan. Petugas pajak belum melakukan penilaian ulang, dengan alasan kurangnya petugas lapangan yang bertugas melakukan penilaian, jarak objek pajak yang akan dilakukan penilaian, dan biaya.

Penelitian dapat dirumuskan bahwa, penetapan NJOP tanah dan bangunan terhadap harga jual pada kawasan perumahan dan perkampungan di Kecamatan Muara Satu tidak sesuai dengan tingkat yang diinginkan. Dan penetapan NJOP tanah dan bangunan terhadap harga jual tanah dan bangunan baik pada perumahan maupun perkampungan di Kecamatan Muara Satu juga belum ditentukan secara seragam. Adapun upaya yang dilakukan DPKAD dalam penetapan NJOP tanah dan bangunan yaitu untuk tahun 2017 NJOP tanah dan bangunan pada perumahan rata-rata naik dua (2) kelas dan untuk perkampungan ratia-rata naik satu (1) kelas. Namun dengan penetapan NJOP yang baru, NJOP tetap masih di bawah harga pasar karena tingkat kenaikannya sangat kecil, maka pengaruhnya terhadap level of assessment pun juga kecil.

\section{KESIMPULAN DAN SARAN Kesimpulan}

Berdasarkananalisidanhasilpembahasan yang telahdilakukansebelumnya, makaolehpenelitidapatmenarikkesimpulansebagaib erikut :

1. AssessmentRatio pada Kelurahan-Kelurahan di Kecamatan Muara Satu Kota Lhokseumawetidak sesuai dengan Assessment Ratio yang ditetapkan oleh Pemerintah Daerah yakni minimal $80 \%$.Kelurahan yang ada di Kecamatan MuaraSatumemiliki Assessment Ratio yangtidak sesuai dengan ketentuan ini, yaitu Kelurahan BatuphatTimurdengan Assessment Ratiosebesar $\quad 54,2 \%$

KelurahanBlangPulodenganAssessment Ratio sebesar 98,5\%, dan Kelurahan UjongPacudenganAssessment Ratiosebesar $74,5 \%$. Dengan kata lain bahwapenetapan NJOP

masihdibawahhargapasarnyaataudengan kata lain terjadiunder assessment.

2. HasilpengukuranTedensiSentral Level of Assessment penetapan NJOP di wilayah KecamatanMuaraSatutidak berada dalam interval standarInternational Association of Assessing Officers (IAAO) yaitu sebesar 90\% sampai dengan $110 \%$. Hal ini terlihat dari perhitungan mean dibagi dengan median yaitu sebesar 1,376 dan dari perhitungan mean dibagi weighted mean sebesar 2,647. Perhitungan ini menunjukkanterjadinyaover assessmentdanterjadinya regresivitas di Kecamatan MuaraSatu Kota Lhokseumawe.

3. PengukuranVariabilitas NJOP di KecamatanMuaraSatu Kota Lhokseumawe telah ditetapkan pada tingkat penilaian yang tidak sama atau tidak seragam. Hal ini dilihat dari perhitungan COD sebesar 79,636\%, yangmelebihidari standar COD IAAO yaitu kurang lebih dari $20 \%$ dan perhitungan COV sebesar $92,602 \%$ yangtidak memenuhi standar COV IAAO yaitu lebih dari $25 \%$.

\section{Saran}

Berdasarkankesimpulananalisis yang telahdilakukanolehpeneliti, makapenelitidapatmemberikan saran sebagaiberikut : 
1. Mengingat Assessment Ratio di Kecamatan MuaraSatu Kota Lhokseumawe masih ada yang dibawah nilai pasar maka dipandang perlu untuk ditingkatkan pada presentase 90\%sampaidengan $110 \%$ sesuai dengan standar yang ditetapkan oleh IAAO dan perlu dilakukan penilaian ulang (re-appraisal) terutama untuk wilayah yang mengalami peningkatan nilai tanah yang pesat. Hal ini dimaksudkan agar rasa keadilan didalam penetapan NJOP tanah dapat terwujud.

2. Karena Nilai Pasar sebagai dasar penentuan NJOP bersifat dinamis, yaitu selalu mengikuti perkembangan yang terjadi setiap saat, maka hendaknya KPP Pratama Kota Lhokseumaweharus melakukan pendataan dan penilaian objek pajak secara berkesinambungan sesuai dengan kondisi terbaru dari objek pajak sehingga data nilai pasar yang diperoleh lebih up to date dan penetapan NJOP tidak terlalu jauh dari nilai pasar.

3. Mengantisipasi gejolak yang terjadi di masyarakat akibat peningkatan pengenaan Assessment Ratio, sebaiknya KPP Pratama Kota Lhokseumawe bersama-sama dengan Pemerintah KotaLhokseumawe meningkatkan pelayanan, mengadakan penyuluhan dan pemberian informasi kepada masyarakat tentang pemanfaatan uang yang mereka bayar.

4. Untuk meningkatkan Penerimaan Daerah, sehubungandengan dikeluarkannya keputusan pemerintah yaitu PBB disetorkan ke pemerintah daerah per tahun 2013, makaperlunya diberikan sosialisasi kepadamasyarakat tentang pemanfaatan pajak yang mereka bayar, yang dapat bermanfaat langsung bagi daerah tempat masyarakat tersebut tinggal.

\section{DAFTAR PUSTAKA}

Darwin, MBP. 2009. Pajak Bumi Dan Bangunan dalam tataran praktis. Mitra Wacana Media. Jakarta.

Direktorat Jenderal Pajak dalam Tata Cara Perhitungan Masing-masing, Key Performance Indicator (KPI) Lampiran 1 SE-18/PJ.22/2006 Tanggal 25 Desember 2017.

Firmansyah. (2008). Analisa Tingkat Akurasi Penetapan Nilai Jual Objek Pajak (NJOP) Bumi Terhadap NilaiPasar dengan Metode Assessment Sales Ratio (Studi kasus di KPP kecamatan Kaliwates Kabupaten Jember). Dapat di akses

http://jurnalskripsi.com/analisatingkat-

akurasi-penetapan-njopbumi-terhadap-nilaipasar-denganmetode-assessment-sales-ratio- $\underline{\text { studikasus-di-kecamatan- }}$

kaliwateskabupaten-jember-pdf.htm

Desember 2017

Fitriandi, dkk. 2010. Kompilasi UndangUndang Perpajakan Terlengkap 2010. Salemba Empat, Jakarta.

Harjanto, Budi, 2000. Konsep Dasar Penilaian Properti, Direktorat Jendral Pajak, Direktorat Pajak Bumi dan Bangunan, Semarang.

Hartoyo, 1998, Assessment Ratio Suatu Alat Pengukur kinerja Penilaian dalam Pelaksanaan PBB,Modul Penilaian II, Jakarta.

Hasan, Iqbal. 2006. Analisis Data Penelitian Dengan Statistik. PT. Bumi Aksara, Jakarta.

http://alhy-zatya.blogspot.com/2012/06/nonprobability-sampling-accidental.html Agustus 2018

https://www.eurekapendidikan.com/2015/09/defeni si-sampling-dan-teknik-sampling.html 28 Agustus 2018

Indriantoro, Nur., Supomo Bambang. 2012. Metode Penelitian Bisnis untuk Akuntansi \& Manajemen. BPFE. Yogyakarta

International Association Assesing Officers (IAAO), 1990, Standard on Ratio Studies Chicago.

International Association of Assessing Officers (2010), Standard on Ratio Studies, Missouri: International Association of Assessing Officers

Kementrian Keuangan Republik Indonesia. 2002. Surat Edaran Direktur PBB \& BPHTB Nomor : SE-01/PJ.6/2002 Tentang Pelaksanaan Analisis Assessment Sales Ratio Sebagai Alat Uji Akurasi NJOP Bumi Terhadap Nilai Pasar Tahun 2002. Jakarta.

Keputusan Menteri Keuangan RI. 2012. Nomor : KEP-291/WPJ.16/2012 Tanggal 06 Desember 2012 Tentang Penetapan NJOP Sebagai Dasar Pengenaan PBB Kota Manado. Jakarta.

Lubis, Irwansyah., Gustin, Djuanda., Ardiansyah, Lubis. 2010. Review Pajak. Salemba Empat, Jakarta.

Mardiasmo. 2011. Perpajakan, Andi, Jakarta.

Meliala, Tulis S dan Fransisca Widianti Oetomo.2010. Perpajakan dan Akuntansi Pajak. Jakarta : Semesta Media

Novie, Amelia Sandra. 2010. Analisis tingkat akurasi penetapan NJOP terhadap nilai pasar dengan metode Assessment Sales 
Ratio (Studi kasus di Kecamatan Kelapa Gading Kotamadya Jakarta Utara). Skripsi. Institut Bisnis dan Informatika Indonesia. Jakarta. http://eprints.unisbank.ac.id/182/

Paat, Elriza. 2012. Tingkat Akurasi Penetapan NJOP Bumi Terhadap Nilai Pasar Dengan Metode Assessment Sales Ratio di Kecamatan Sario Kota Manado. Fakultas Ekonomi Universitas Sam Ratulangi, Manado.

Pemerintah Republik Indonesia. 1994. UndangUndang No.12 Tahun 1994 Tentang Perubahan UndangUndang Pajak Bumi dan Bangunan. Jakarta.

Prawoto, Agus. 2011. Penilaian Pajak Bumi Bangunan Perdesaan \& Perkotaan. BFPFE, Yogyakarta.

Rahman, Abdul, (2010), Administrasi Perpajakan, Jakarta: Penerbit Nuansa Cendikia

Rezki, vandy. (2010), “Analisa Tingkat Akurasi Penetapan Nilai Jual Objek Pajak (NJOP) Bumi Terhadap Nilai Pasar Dengan Metode Assessment Sales Ratio (Studi Kasus Di Kantor Pelayanan Pajak Pratama Bukittinggi)“‘.

Resmi, Siti. 2011. Perpajakan Teori dan Kasus. Salemba Empat, Jakarta.

Sari, Diana. 2013. Konsep Dasar Perpajakan. Refika Aditama, Bandung.

Skripsi.http://www.google.co.id/url?sa=t\&rct=j\&q $=\&$ esrc $=$ s $\&$ source $=$ web $\& c d=5 \& c a d=$ ja $\& u a$ $\mathrm{ct}=8 \&$ ved $=0 \mathrm{CDoQFjAE} \& u r l=\mathrm{http} \% 3 \mathrm{~A} \% 2 \mathrm{~F}$ $\% 2$ Fejournal.unsrat.ac.id\%2Findex.php $\% 2 \mathrm{~F}$ emba\%2Farticle\%2Fdownload\%2F2917\%2 F2468\&ei=_f9bVfv7Lc2ruQSRtoDABg\&us $\mathrm{g}=\mathrm{AFQjCNHITELIXs34dmjfjVlaKsNmW}$ MhgEA\&bvm=bv.93756505,d.c2E. Diakses 25 Desember 2017. Hal 1-11.

Sugiyono. 2010. Metode Penelitian Bisnis. Alfabeta, Bandung.

Sunyoto, Danang. 2013. Metodologi Penelitian Akuntansi. PT. Refika Aditama, Bandung.

Supramono \& Damayanti Woro Theresia, 2010. Perpajakan Indonesia Mekanisme dan Perhitungan. Andi Yogyakarta. Yogyakarta.

Surat Edaran 09/PJ.06/2003, Tentang Standar Assessment Sales Ratio

Surat Edaran Direktur PBB dan BPHTB Nomor : SE-09/PJ.06/2002, Tentang Penerapan NJOP Sama Dengan Nilai Pasar.

Suryawati, dkk. 2010. Analisa Penetapan NJOP (Nilai Jual Objek Pajak) Bumi Terhadap Nilai Pasar Dengan Menggunakan Metode Assessment Sales
Ratio (Studi Kasus di Kecamatan Kamal). Fakultas Ekonomi Universitas Trunojoyo, Bangkalan. Tugas Akhir.

Undang-Undang No 12 Thun 1994 Tentang Perubahan UndangUndang Pajak Bumi dan Bangunan.

Undang-Undang No. 20 Tahun 2000, Tentang Bea Perolehan hak Atas Tanah dan Bangunan

Utah Komisi Pengawas Pajak Negara, 2004, Divisi Pajak Kekayaan Assessment/Sales Studi Perbandingan

Waluyo. 2011. Perpajakan Indonesia Edisi Revisi 2011. Salemba Empat, Jakarta.

Wakas Menthari, 2015. Analisis tingkat akurasi penetapan NJOP bumi di Kecamatan Mapanget Kota Manado. Skripsi. Fakultas Ekonomi dan Bisnis, Universitas Sam Ratulangi Manado. http://ejournal.unsrat.ac.id/index.php/emba/a rticle/view/8358. Diakses 08 Desember 2017. Hal. 1-9

Yulihardi. 2008, PedomanPenulisan Proposal Penelitian \& Skripsi, Padang, Universitas Putra Indonesia 